\title{
SIMULATION STUDY OF THE DIGITAL TEMPERATURE SENSOR OPERATION IN CASE OF A NON-STANDARD MECHANICAL IMPACT OF THE NPP EQUIPMENT
}

\author{
Y.M. Bikovsky ${ }^{1}$, O.V. Derevianko ${ }^{1}$, V.V. Levchenko ${ }^{2}$, A.Y. Pogosov ${ }^{1}$ \\ ${ }^{1}$ Odessa National Polytechnic University, Odessa, Ukraine \\ E-mail:bym.evrika@gmail.com,ov_derevianko@ukr.net,pogosov@ukr.net; \\ ${ }^{2}$ Zaporizhzhya NPP, Energodar, Ukraine \\ E-mail: levmaster77@gmail.com,
}

The article presents the results of an experimental study relevant to the effective organization of temperature control of thermomechanical equipment at nuclear power plants (turbines, pumps, steam generators, deaerators, etc.). Bench studies of the reaction of the DS18B20 digital intelligent temperature sensor, which is supposed to be introduced at Ukrainian nuclear power plants, to the application of external compression force to its body, which may occur under conditions typical for the operation of equipment operating at nuclear power plants, have been carried out. An electrical circuit diagram has been developed for a reset signal simulation device (for bench modeling of a sensor application system). The issues of identifying a sign in the sensor output signal informing about the effect of an external compression force on its body are considered. The technique of bench experiments and processing of research results necessary to address the issue of introducing new digital measuring equipment for temperature control of thermomechanical equipment of nuclear power plants is given.

\section{INTRODUCTION}

At the enterprises of the nuclear energy industry during the operation of technological equipment there are various negative factors affecting the operation of measuring instruments used to monitor technological processes. These factors can lead to an increase in the random component of the error of the measurements taken in industrial operation. Factors of negative influence on certain sensors by electromagnetic fields that occur at nuclear power plants can be largely eliminated by shielding measuring instruments and transmitting measuring signals: the use of protective covers, various types of insulation, etc. However, it is impossible to get rid of some factors, including mechanical influences among them, so you have to make corrections to the measuring signals or use more "rough" measurement results, which reduces the reliability of the information received (that is, information received from the measuring equipment in the form of signals).

At present, analog thermal sensors installed in metal sockets are still widely used at Ukrainian nuclear power plants, which, for example, under transient operating conditions of a power unit, under temperature changes, undergo temperature stresses and deformations or, in emergency situations, experience mechanical effects negatively affecting the sensors load. Structurally, the thermoresistors and thermocouples traditionally used at nuclear power plants as analog primary measuring transducers are strong enough to protect their sensitive elements from external mechanical influences, but they are significantly inferior in their operational characteristics (in accuracy and noise immunity of the signal) to digital temperature sensors (i.e. sensors with digital output signals), considered as an additional means of information support for the work of power engineering, which in the near future should be integrated into computer control systems for technological equipment of nuclear power plants [1-3]. This circumstance is largely decisive in the issues of reequipping energy production with modern digital measuring devices - that is, the strategy for the transition from analog measuring instruments to digital should be based on comprehensive preliminary studies of the proposed measuring instruments for implementation.

However, there are factors that significantly limit the possibilities of upgrading temperature channels at nuclear power plants and, first of all, they include the almost complete absence of objective (that is, based on bench experimental studies) information on the operability of digital temperature sensors proposed for implementation in nuclear energy production in nonspecific for them (conditions not assumed during the development (based on the nameplate characteristics) namely, under conditions of mechanical stress on the body. At the same time, the transition to digital processing of measuring signals is becoming increasingly important in nuclear power plants [4].

Some of the alleged limitations with regard to intelligent digital temperature sensors, among which the DS18B20 should be highlighted, include the completely unexplored effect of mechanical pressure on their housing and the influence of mechanical vibrations (except for the obvious effects of magnetic and radiation fields), the manifestations of which are characteristic of the technological process conversion of thermal energy into mechanical (and then electrical) at a nuclear power plant. This circumstance determines the relevance of this kind of research for nuclear energy in Ukraine $[5,6]$.

In general, the relevance of the research is also associated with the current trend of transition to digital methods of transmitting primary measuring signals [7]. 
An analysis of literary sources shows that one of the most significant destabilizing factors in the operation of any digital sensor in operating conditions at nuclear power plants is the mechanical effect on its body $[8,9]$. This fully applies to temperature sensors used to monitor the condition of materials in nuclear power engineering. However, without specially organized studies, it is not possible to predict the behavior of a digital sensor located in the zone of influence of this factor. In particular, in the accompanying documentation of the sensor manufacturer (Dallas Semiconductor, which is the leading provider of digital sensors in the world market), this information is completely absent.

At the nuclear power plant, various thermomechanical equipment is used, the monitoring of the state of materials of which is increasingly carried out using digital measuring equipment. At the same time, the cyclic redundancy check code CRC (Cyclic redundancy check) is widely used - an algorithm that provides for checking the checksum of elements of a digital signal (0 and 1 ), designed to monitor data integrity in a measuring signal. CRC is a common practical error-correcting coding software application for checking the reliability of transmitted signal information, but this code does not take into account the influence of external negative factors. Therefore, when the end device (data processing system) receives a distorted signal from the primary sensor and is guided only by checking the standard CRC code, the user (operator) may receive false (false) information about the processes under study or not at all if the code does not match the expected one.

An analysis of the publications [10,11] suggests that the effect of the compression force on its body remains an unexplored issue of the effect on temperature sensors.

The main goal of this work is to analyze the technological behavior of the digital (intelligent, algorithmically processing information) DS18B20 temperature sensor under the influence of mechanical factors inherent in nuclear power facilities. In this regard, the task arose to experimentally determine how an increase in the compression force of the body of the digital thermal sensor will affect the measuring ability of the converter, taking into account the need for its use to monitor the state of materials at nuclear power plants. It was also necessary to find out - if such a factor affects, then to what extent is this influence acceptable in terms of the reliability and accuracy of the received measuring signal. In addition to those presented above, the question of the limits of the susceptibility of the DS18B20 to external compression of the sensor housing also remained open. The solution to these problems is a continuation of our research that preceded this, the results of which were published earlier [12-15].

\section{CONDUCTING EXPERIMENTS}

Since one of the most effective destabilizing factors during the operation of a digital temperature sensor in nuclear power plants is mechanical impact, studying the limits of the susceptibility of sensors to workloads of this type will take into account the influence of this factor when modernizing the measuring channels.

Considering the fact that there is no complete information on the strength and signal-mechanical characteristics of the DS18B20 sensor in the literature, this object was presented in the form of a "black box" with unknown properties: as you know, this is a method of researching an object, when instead of the properties and interconnections of its components, the reaction of the object, as a whole, to changing conditions is studied [16]. And, first of all, the issue of identifying the sign of the sensor's response (an indicator of its sensitivity to external influences) to the force applied to the body was resolved.

In Fig. 1 shows a photo of the investigated sensor. It has three conclusions, only one of which is informational, and is intended for receiving (transmitting) signals (it was this conclusion that was used as a channel for receiving information, depending on the external mechanical effect on the sensor). As follows from the technical description of the MicroLan network [17], the information management computer system interacts with the sensor via a digital communication channel through this information output sequentially, therefore, under the conditions of the task, it is the only source of information about the sensor status [18].

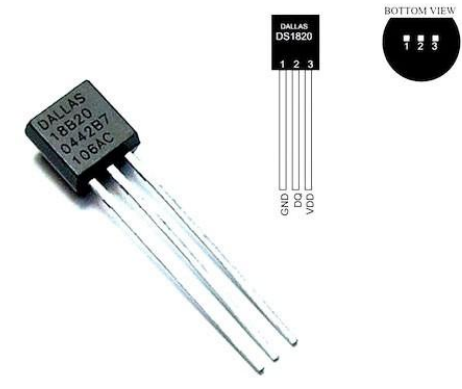

Fig. 1. Appearance of the temperature sensor DS18B20

A laboratory experiment was prepared taking into account the following. The process of interaction between the computer used in the research (a microcontroller can also be used as such a control and analytical device) with sensors located in the digital signal input line consists in sequentially transmitting requests and commands from the computer to the line and receiving answers from identified ones (using individual 64-bit codes) of the number of sensors connected to the computer.

The duration of each individual measurement cycle is about $750 \mathrm{~ms}$, during which a large amount of information is transmitted, including temperature values, type of sensor, individual serial number, CRC code and control commands. An analysis of a signal of such a duration to solve the problem poses certain difficulties in a bench experiment (high speed of information exchange between a PC and a sensor, as well as a large amount of analyzed information). Therefore, the experimental technique provided for minimizing the information capacity of the signal under study, taking into account the fact that each 
measurement cycle begins with sending an initialization (reset) pulse from the $\mathrm{PC}$ to the line in the form of a voltage drop $\left(U_{\text {OUT }}=0\right)$ with a duration of about $480 \mu \mathrm{s}$. If the line contains a serviceable and ready for information exchange sensor, then after a while it already sends its response to the computer side in the form of a voltage drop, lasting from $60 \mu$ s to $240 \mu \mathrm{s}$ (Fig. 2).

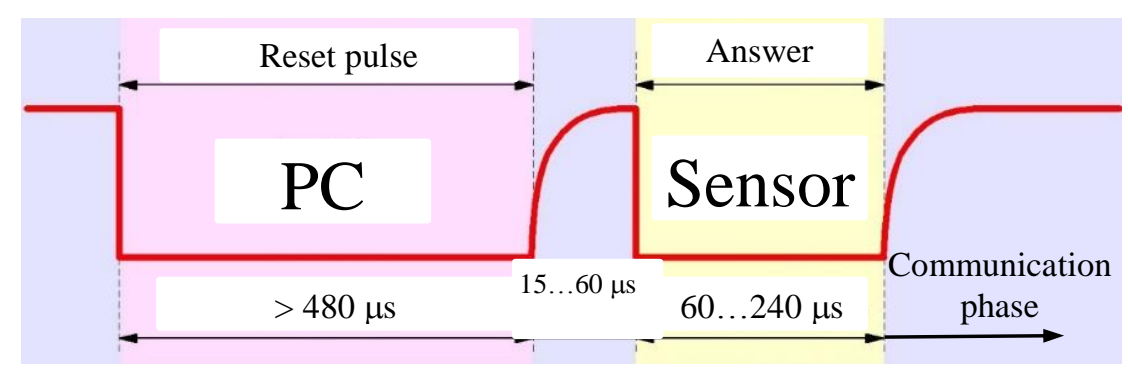

Fig. 2. Graphic illustration of the sensor initialization process

After the sensor response, the PC-sensor signal exchange phase begins. Since in a complex two-way signal it is fundamentally difficult to single out the sensor responses that are of interest to us, the experimental technique provides for taking into account only the first of them formed during the initialization process. The research methodology included physical modeling of this process, which was carried out using a device, a diagram of which is shown in Fig. 3.

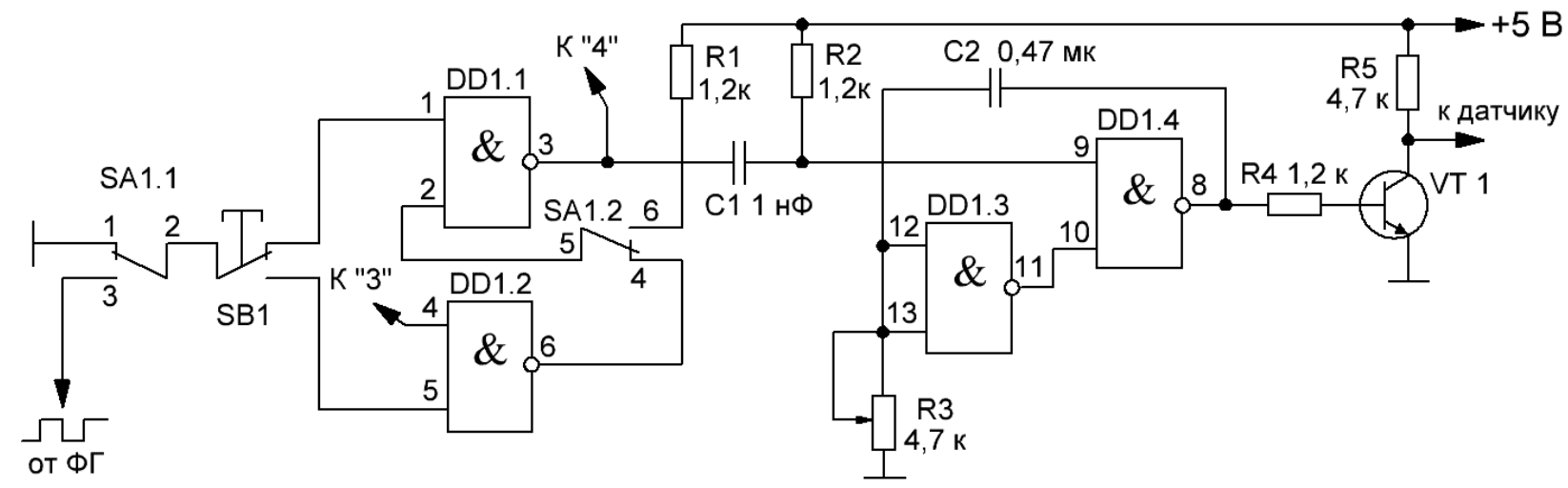

Fig. 3. Electrical circuit diagram of the device simulating the signal "reset" (for bench simulation of the sensor)

In the above diagram, an anti-bounce trigger is assembled on the elements DD1.1 and DD1.2, the input of which is supplied either manually (by pressing the SB1 button) or from a functional generator selected by the switch SA1. The one-shot at the elements DD1.3 and DD1.4 generates a reset pulse, the duration of which can vary over a wide range by the resistor R3. The output stage of the circuit through the resistor R5 provides a pull-up of the signal line of the sensor to a level of plus $5 \mathrm{~V}$ in the pauses between pulses of information exchange.

To conduct an experimental (bench) study of the sensor reaction using the device described above, static pressure was applied to its body from two sides, as shown in Fig. 4. From technological considerations (for the operating conditions of the NPP processing equipment), the most likely direction of mechanical action on the sensor body, is the impact shown in Fig. 4,a, characteristic, for example, in the case of pressing the sensor to the surface of the measurement object to reduce vibration and better contact with the surface of the equipment, but this does not exclude the possibility of exposure as shown in Fig. 4,b.

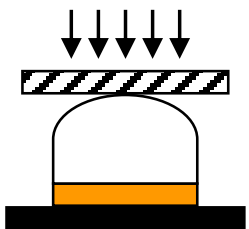

$a$

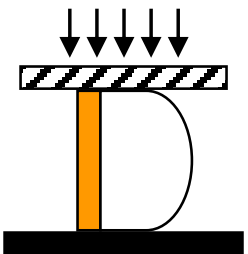

$b$
Fig. 4. Scheme of loading the temperature sensor "from above" (a) and "side" (b)

For the experiment, the sensor was connected to a digital oscilloscope, which is part of the computer equipment of the stand for studying the operation of the sensor.

The sequence of implementation of each research act within the framework of the experiment provided for the following procedures:

- application of mechanical force to the sensor housing;

- formation of a "reset" impulse (using the developed scheme);

- registration and saving of the sensor output signal (using a digital oscilloscope); 
- analytical processing of the signal received from the sensor (as a reaction to the applied force).

In Fig. 5 shows, on an enlarged scale, the graphs of the trailing edge of the sensor response pulse (see also Fig. 2) under the influence of force in two directions taken during the design of the experiment.

The leading edge of the pulse, as shown by experiments, practically did not change in time and, therefore, was not considered by us. The sensor was subjected to an increasing effect of force until it was mechanically destroyed - the experiment was terminated in the absence of an output signal from the sensor. The influence of the vibration factor (i.e. dynamic loads) in the described series of experiments was not studied.

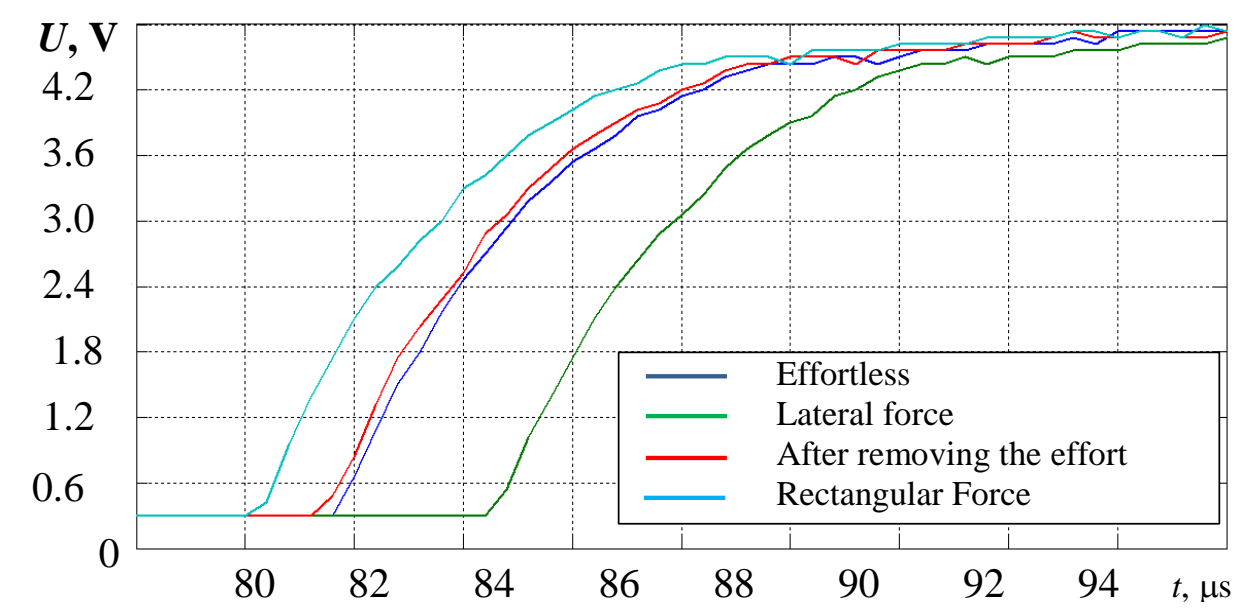

Fig. 5. Trailing edge of the signal from the sensor

The results of the experiments indicate a change in the pulse duration of the sensor signal ("communication phase") at the same mechanical pressure on the housing depending on the direction of the applied force. It was also found that the directions of the displacement of the trailing edge of the pulse in both cases differ significantly.

An analysis of the experimental data leads to the understanding that these differences are due to the topologies of the placement of the crystal in the sensor body (and the corresponding natural frequencies of its vibrations) and, accordingly, different manifestations of deformation effects depending on the direction of compression of the body. In both cases considered, the sensor signal returned to its initial state when the external mechanical effect was removed, which indicates the absence of the "memory" effect, which means that it allows monitoring the trends in the external effect on the sensor during temperature control. This circumstance can be used for diagnostic purposes (in addition to obtaining temperature data at the place of installation of the sensor) - to determine the directions of deformation in the material of equipment where such a sensor will be installed.

Since the results shown in Fig. 5 were estimates (qualitative from the point of view of the feasibility of using the sensor at nuclear power plants), they were used as a basis (basis) for expanding the program of experiments. Further bench studies were carried out to determine the quantitative limits of the mechanical load on the sensor and were carried out by changing the forces from different sides from $0 \mathrm{~N}$ to a value at which the sensor was completely destroyed.
At the same time as conducting the experiment on mechanical compression, temperature measurements were carried out using standard temperature measuring instruments that were not subjected to mechanical stresses to detect differences in the readings of an independent sensor (describe this as an independent sensor) and the test one.

\section{ANALYSIS OF RESULTS}

Fig. 6 shows a graph of the displacements of the trailing edge of the sensor signal when the pressure changes to the "upper" face of its body (Fig. 4,a).

The graphs show a pronounced tendency to decrease the pulse duration with increasing effort.

To analyze the results presented graphically and to obtain functional approximating dependencies, the mathematical apparatus of regression analysis was used as a method for assessing the influence of independent variables (parameters) associated with an object on a dependent parameter, which allows to correlate cause and effect.

So, it was taken into account that, in practice, the dependencies between two random variables, which are represented by the results of their repeated observations, are most often studied [19,20]:

$$
\begin{aligned}
& X=\left\{x_{1}, x_{2}, \ldots, x_{n}\right\}, \\
& Y=\left\{y_{1}, y_{2}, \ldots, y_{n}\right\} .
\end{aligned}
$$

In the presence of a correlation between the random variables $\mathrm{X}$ and $\mathrm{Y}$, a functional dependence $\mathrm{Y}=\mathrm{F}(\mathrm{X})$ takes place.

As is known, the mathematical apparatus of regression analysis suggests that the values of $x_{i}$ and $y_{i}$ are mutually independent and normally distributed. 


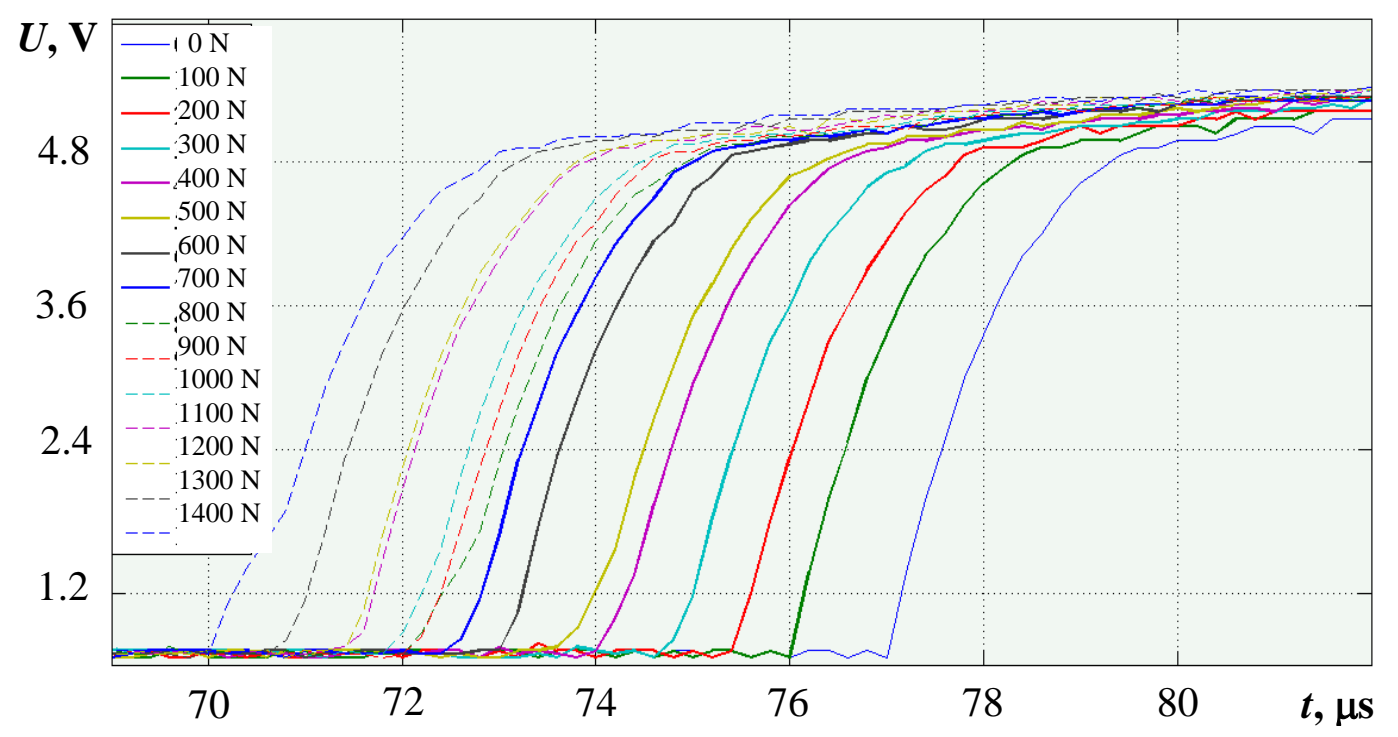

Fig. 6. The offset of the trailing edge of the sensor signal

Due to the fact that it was not possible to select an elementary analytical function that adequately describes the experimental data, regression using a polynomial was applied to obtain a mathematical model of the process under consideration.

The regression equation can be represented as a polynomial of degree $\mathrm{k}$ :

$Q=\sum_{i=0}^{k} B_{i} \cdot x^{i}=B_{0}+B_{i} \cdot x^{i}+\ldots+B_{k} \cdot x^{k}$,

where $B_{i}-$ coefficients of the regression equation, which were found by the least squares method.

The optimal value of the degree of the polynomial $\mathrm{k}$ is found by sequential refinement (an increase in the value of $\mathrm{k}$, starting from $\mathrm{k}=1$ ). The degree of the polynomial is optimal if it provides the smallest value of the residual dispersion $D_{k}$ (the dispersion due to the scatter of experimental points around the regression line). In other words, a sequential increase in $\mathrm{k}$ ensures that the approximating curve approaches the experimental points (i.e., reduces the residual dispersion) until the optimal value of $\mathrm{k}$ is reached, after which its further increase either does not change the dispersion or leads to its increase .

The residual dispersion was determined by the formula

$$
D_{k}=\frac{1}{n-k-1} \sum_{i=1}^{n}\left(y_{i}-y_{i}^{\prime}\right)^{2},
$$

where $\mathrm{n}-$ is the number of experimental points; $y_{i}^{\prime}=f\left(x_{i}\right)$ - values of $Y$ calculated by the regression equation; $\left(x_{i}, y_{i}^{\prime}\right)$ - the coordinates of the experimental points.

The initial analysis led to the conclusion that in our case, with this regression equation, at each step of refining the degree of the polynomial, it is necessary to recalculate all $\mathrm{Bi}$ coefficients. Therefore, it was decided to simplify the calculations by writing the regression equation using Chebyshev polynomials $\mathrm{Pi}(x)$ :

$$
Q=\sum_{i=0}^{k} A_{i} P_{i}(x)=A_{0} P_{0}(x)+A_{1} P_{1}(x)+\cdots+A_{k} P_{k}(x) .
$$

Chebyshev polynomials of the first and second orders have the form:

$$
\begin{gathered}
P_{0}(x)=1, \\
P_{1}(x)=x-\bar{X}=x-\frac{1}{n} \sum_{i=1}^{n} x_{i} .
\end{gathered}
$$

Chebyshev polynomial of arbitrary order $P i(x)$ can be found knowing the polynomials of the two previous orders $P_{i-1}(x)$ и $P_{i-2}(x)$ :

$$
\begin{gathered}
P_{i}(x)=\left(x+\alpha_{i}\right) P_{i-1}(x)+\beta_{i} P_{i-2}(x), \\
\alpha_{i}=\frac{\sum_{j=1}^{n} x_{j} \cdot P_{i-1}^{2}\left(x_{j}\right)}{\sum_{j=1}^{n} P_{i-1}^{2}\left(x_{j}\right)}, \\
\beta_{i}=\frac{\sum_{j=1}^{n} x_{j} \cdot P_{i-1}\left(x_{j}\right) \cdot P_{i-2}\left(x_{j}\right)}{\sum_{j=1}^{n} P_{i-2}^{2}\left(x_{j}\right)},
\end{gathered}
$$

where $P_{i-1}\left(x_{j}\right), P_{i-2}\left(x_{j}\right)$ - Chebyshev polynomials at the points $\mathrm{xj}$ (calculated by substituting the results of observations $\mathrm{xj}$ into polynomials).

Moreover, the coefficients of the regression equation are found by the formula:

$$
A_{i}=\frac{\sum_{j=1}^{n} y_{j} \cdot P_{i}\left(x_{j}\right)}{\sum_{j=1}^{n} P_{i}^{2}\left(x_{j}\right)} .
$$

Thus, at each step of refining the degree of the polynomial $\mathrm{k}$, only one coefficient was calculated using the well-known formula, which reduced the amount of calculations and simplified the methodology for analyzing the experimental results. In addition, the calculations of the residual variance were simplified, since there was no need to calculate the regression residues.

The value of $D_{k}$ was found by the formula:

$$
D_{k}=\frac{S_{k}}{n-k-1}
$$




$$
\begin{aligned}
& S_{0}^{2}=\sum_{i=1}^{n} y_{i}^{2}-\frac{1}{n}\left(\sum_{i=1}^{n} y_{i}\right)^{2}, \\
& S_{k}^{2}=S_{k-1}^{2}-A_{k}^{2} \sum_{i=1}^{n} P_{k}^{2}\left(x_{i}\right) .
\end{aligned}
$$

In the case of applying the force to the sensor "from above" (see Fig. 4,a) as a result of the calculations performed during the analysis, the following results were obtained. form:

The regression equation for $\mathrm{k}=1$ is obtained in the

$$
y=197.64+38.527(x-19.64) .
$$

The value of the residual dispersion was:

$$
D_{1}=3197.87456 \text {; }
$$

$$
\begin{gathered}
D_{2}=1084.07835 ; \\
D_{3}=1275.08367 .
\end{gathered}
$$

Since $\mathrm{D} 2<\mathrm{D} 1$ and $\mathrm{D} 2<\mathrm{D} 3$, the second-order regression equation, as we can conclude, more accurately describes the experimental data than the third-order regression equation and, taking into account the above, is thus optimal for the analytical description the results obtained.

Thus, the dependence of the response time of the sensor on the magnitude of the applied mechanical load, in the case of pressure on the rectangular face of the sensor:

$$
y_{\Pi}=-13.680 x^{2}-77.807 x-1142.399 .
$$

The results of studies of the sensor response under mechanical action on its lateral face (see Fig. 4,b) are shown in Fig. 7.

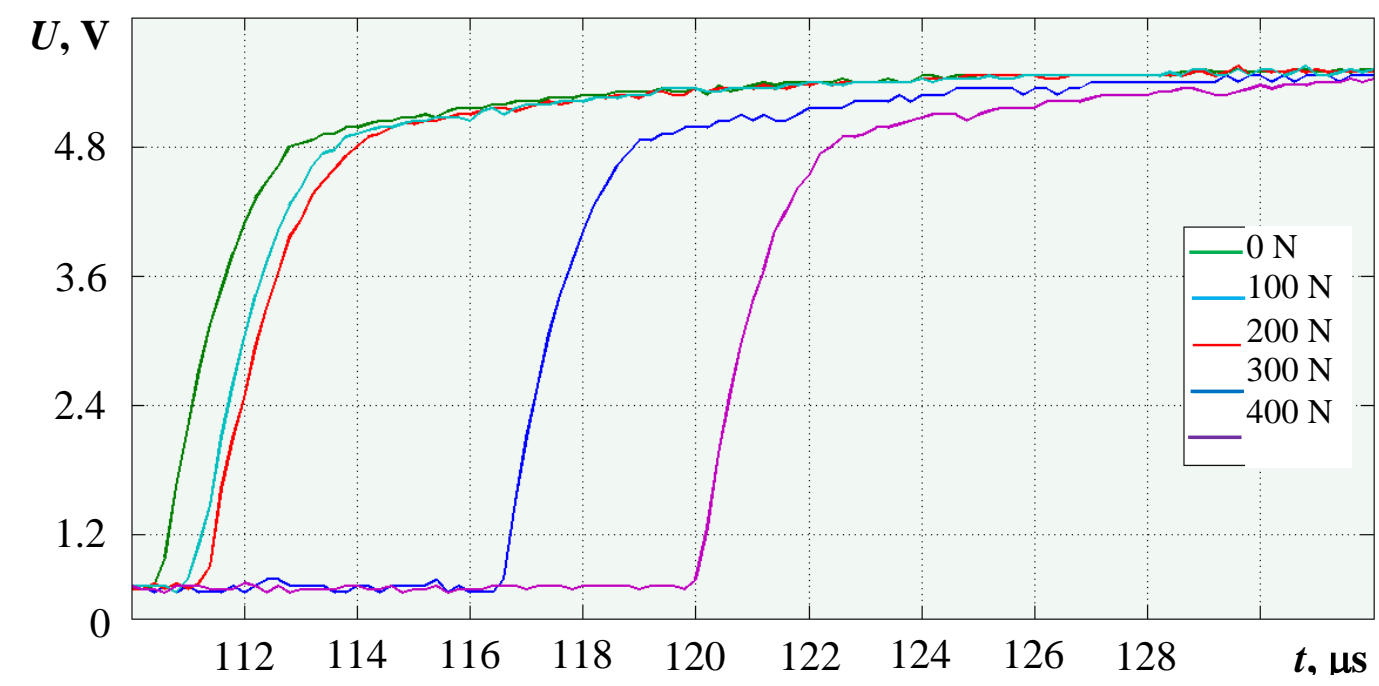

Fig. 7. Displacement of the trailing edge of the sensor signal with increasing force on the side face

As experimental studies have shown, the mechanical effect in the lateral direction turned out to be more dangerous for the sensor than in the previous case - such an effect led to its destruction even with an impact force of $400 \mathrm{~N}$.

The function that describes the dependence of the sensor response pulse duration on the magnitude of the force applied to its lateral face, determined by the analysis method considered above, has the form:

$$
y_{\text {Б }}=-0.0443 \cdot x^{2}-11.1375 \cdot x-15.7404 \text {. }
$$

During the experiment, a similar DS18B20 sensor was used as a reference temperature sensor (blue curve), the metrological characteristics of which were checked using an ATC-156B reference temperature calibrator. The second temperature sensor was subjected to force (red curve), dashed lines show the maximum permissible absolute values of the temperature sensor $\pm 0.5{ }^{\circ} \mathrm{C}$. Shown in fig. The curves 8 and 9 made it possible to analyze the change in the standard output signal of the temperature sensor under study for various directions of the force applied to its body.

As can be seen from Fig. 8, the planar mechanical effect (on a flat face) is practically not detected by the electronic measuring circuit in any way up to a force of $400 \mathrm{~N}$. At the same time, the detected information sign (the duration of the sensor response pulse) overcame almost half of its maximum change (see Fig. 6), which indicates its high stability.

The impact on the side face of the sensor began to be reflected in its output signal even with small changes in force (Fig. 9). As can be seen from Figs. 8 and 9, the value of the basic absolute error exceeds the permissible limits of $\pm 0.5^{\circ} \mathrm{C}$, declared by the manufacturer. This circumstance should be taken into account, because receiving false information about the flow of the technological process at nuclear power plants is unacceptable. 


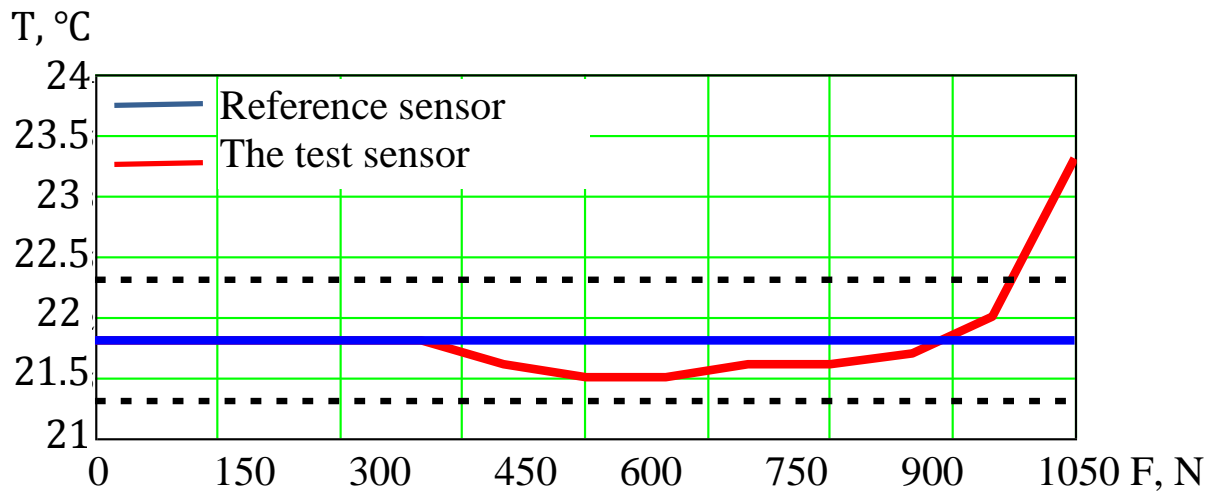

Fig. 8. Graph of the output signal of the temperature sensor at change of pressure "from above"

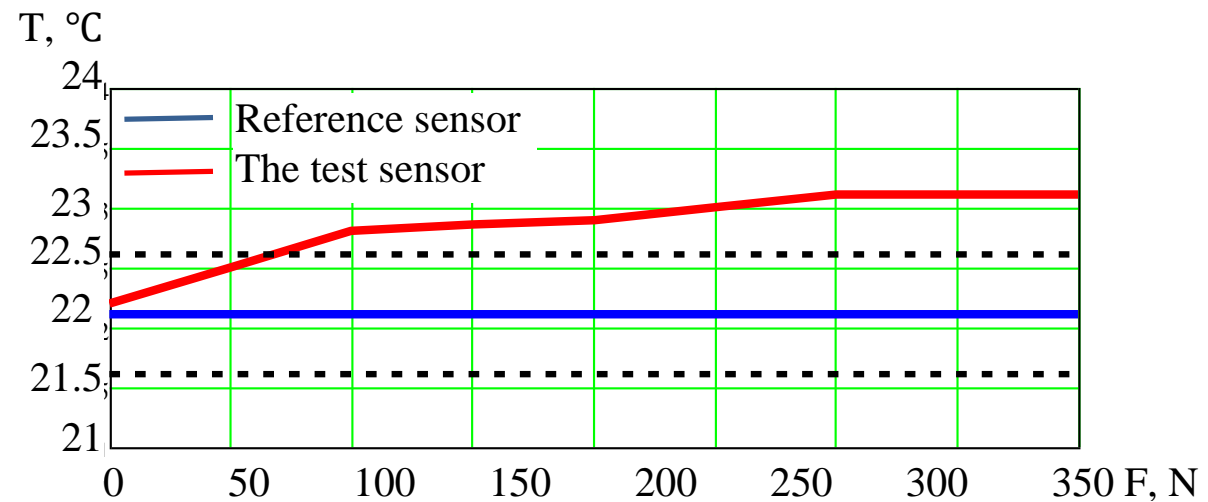

Fig. 9. Graph of the output signal of the temperature sensor when changing the pressure "side"

\section{THE DISCUSSION OF THE RESULTS}

As a result of the studies, experimental confirmation of the assumption of the influence of mechanical force on the shape of the output signal was obtained. The dependences of the sensor output signal on the amount of applied force are determined. This is important for understanding the possibilities of using in the conditions of work at nuclear power plants in order to prevent erroneous notification of operators about the presence of a malfunction (i.e., a deviation in the technological system or process), which may require corrective action on the part of the operator.

The results can be used to conduct further research (to determine the operability of the sensor in the event of vibration or ionizing radiation) or to decide on the use of sensors in nuclear power plants based on the obtained experimental data. "

Empirically, an information sign was identified that allows you to timely remotely detect the presence of mechanical pressure on the sensor housing without the need for access to it.

Experimental studies of the remotely controlled reaction of the temperature sensor were carried out, with the application of force to its body. When conducting bench experiments, it was found that under the action of compression forces up to $1350 \mathrm{~N}$ (when exposed as shown in Fig. 4,a) and up to $60 \mathrm{~N}$ (when exposed as shown in Fig. 4,b) the temperature readings of the sensor practically coincide with the control data (reference) thermometer located next to the probe under study. This indicates the stability of the digital sensor and, undoubtedly, refers to its advantages. However, a further increase in the force on the sensor by only $30 \mathrm{~N}$ (in the first case) and $10 \mathrm{~N}$ (in the second case) distorted the output signal. This can be considered as an information sign of the achievement of a dangerous limit of mechanical impact on the sensor - that is, as a sign by which it is possible to judge the fact of achievement by force of a level, exceeding which signals the unreliability and inexpediency of further accounting of measurement results. The basis for such a judgment is that, after exceeding the force of the indicated level, the physical destruction of the measuring transducer occurred, which showed the limitations of the use of the sensor for temperature monitoring on equipment capable of mechanical deformation.

The described approach to the processing of the output signal can be performed in real time to prevent the formation of alarms using false information arising from failures of the sensors generating the output signals.

\section{CONCLUSIONS}

One of the issues of using a digital temperature sensor to control the technological process of nuclear power plants was considered: the effect of increasing the compression force on the housing of the DS18B20 sensor, planned for use at nuclear power plants, at least on the equipment of a steam turbine installation. Bench experimental studies were conducted, the results of which revealed the permissible limits of the parameters 
of mechanical action on digital temperature sensors planned for implementation at nuclear power facilities, which allows us to expand the program of further research aimed at the scientific support of modernization of control systems for monitoring the condition of materials in nuclear power engineering equipment.

The ultimate goal of bench experiments and mathematical modeling, provided that the sensors under consideration are put into operation of NPPs, can be the creation of appropriate software and hardware systems as elements of expert systems to support the operator of nuclear energy facilities and other industrial enterprises whose technological process requires temperature control.

The results obtained in the course of an experimental study can narrow the range of problems in the field of atomic science and technology in terms of adequate monitoring of the temperature of the power equipment of nuclear power plants using computerized digital measuring instruments.

\section{REFERENCES}

1. M.Yu. Okhtilev, B.V. Sokolov, R.M. Yusupov. Intelligent technologies for monitoring and controlling the structural dynamics of complex technical objects. M.: "Nauka", 2006, 410 p.

2. V.B. Trofimov, S.M. Kulakov. Intelligent automated systems for managing technological objects // International Journal of Experimental Education. 2016, N 12 (part 1), p. 113.

3. J.F. Canete. System Engineering and Automation: Interactive Educational Approach Springer. 2011, 268 p.

4. NS-G-1.3 IAEA Safety Standards Series. Instrumentation and control systems important to the safety of nuclear power plants. Guide.

5. S.P. Gubarev, A.V. Leonovich, R.M.Muratov, Y.N. Nezovibatko, G.P. Opaleva, V.S. Taran, M.I. Zolototrubova Hardware-software complex for automated control and monitoring of the vacuum system of the BULAT-6 installation // PAST. 2019, N 1(119), p. 135-137.

6. V.S. Osadchuk et al. Influence of pressure on the parameters of semiconductor structures: Naukovi praci VNTU, 2009, N 1, p. 1-5.

7. IEC 62241:2004 Nuclear power plants Main control room Alarm functions and presentation.

8. IEC 62262: 2002 Degrees of protection provided by enclosures for electrical equipment against external mechanical impacts (IK code).
9. DS18B20. Technical description.

10. A.Yu. Pogosov, O.V. Derevyanko. Metrological support of NPP operation. Odessa: "Science and technology", 2016, $204 \mathrm{p}$.

11. I. Gertsbakh, Y. Shpungin. Network Reliability. Springer, 2020, 95 p. (Springer Briefs in Electrical and Computer Engineering).

12. Yu.M. Bykovsky, V.V. Levchenko. On the assessment of the possibility of using digital sensors in temperature measurement channels at Ukrainian NPPs: Sat scientific works of SNUYaEiP N 3(35), 2010, $280 \mathrm{p}$.

13. Yu.M. Bikovskiy, V.V. Levchenko, O.Yu. Pogosov. Experimental testing of the influx of electromagnet fields on digital temperature sensors with single-mouth lines for monitoring the operation of AIC systems in AEC control systems // Nuclear and Radiation Free Shop. 2019, N 2(82).

14. V.V. Levchenko, Y.M. Bykovsky, O.Y. Pogosov. New possibilities of application of digital measuring transducers for control of temperature fields at the stage of decommissioning of NPP power units and monitoring of the state of the environment // Problems of decommissioning of nuclear power facilities and environmental restoration (INUDECO 19): Proceedings of the IV International Conference April 2019, Slavutych). Chernihiv: ChNTU, 2019, p. 136-146.

15. A.Yu. Pogosov, V.V. Levchenko, Yu.M. Bikovsky. Analysis of Prospects for Application of Intellectual Digital Temperature Sensors in Data Channels of On-Line Control Means at Nuclear Power Plants // Material of Conference IEEE (ESS) (17-19 April 2019, Kyiv, Ukraine) p. 76-79.

16. V.N. Volkova, A.A. Denisov. Theory of systems and system analysis: a textbook for bachelors. M.: "Publishing House Yurayt"; ID Jurayt, 2012, 679 p.

17. MicroLAN network interface [Electronic
[ resource]. - Access mode: http://icmicro.narod.ru/info_ru/microlan/microlan.htm.

18. 1-Wire and iButton datasheet.

19. Handbook of Applied Statistics. In 2 volumes: Per. with English / Ed. E. Lloyd, W. Lederman, Y.N. Tyurina. M.: "Statistics", 2009, 510 p.

20. I.F. Stefan. Mathematical methods of experimental data processing. Kemerovo: GUKuzGTU, 2008.

\section{ИМИТАЦИОННЫЕ ИССЛЕДОВАНИЯ РАБОТЫ ЦИФРОВОГО ДАТЧИКА ТЕМПЕРАТУРЫ ПРИ НЕСТАНДАРТНОМ МЕХАНИЧЕСКОМ ВОЗДЕЙСТВИИ ОБОРУДОВАНИЯ АЭС}

\section{Ю.М. Быковский, О.В. Деревянко, В.В. Левченко, А.Ю. Погосов}

Представлены результаты экспериментального исследования, актуального для эффективной организации контроля температуры тепломеханического оборудования на АЭС (турбин, насосов, парогенераторов, деаэраторов и др.). Проведены стендовые исследования реакции цифрового интеллектуального датчика 
температуры DS18B20, предполагаемого к внедрению на АЭС Украины, на приложение внешней силы сжатия на его корпус, которая может возникнуть в условиях, характерных для эксплуатации действующего на АЭС оборудования. Разработана электрическая принципиальная схема устройства имитации сигнала «сброс» (для стендового моделирования системы применения датчика). Рассмотрены вопросы выявления в выходном сигнале датчика признака, информирующего о воздействии внешней силы сжатия на его корпус. Приведена методика проведения стендовых экспериментов и обработки результатов исследований, необходимых для решения вопроса о внедрении новых цифровых средств измерительной техники для контроля температуры тепломеханического оборудования АЭС.

\title{
ІМІТАЦЙНІ ДОСЛІДЖЕННЯ РОБОТИ ЦИФРОВОГО ДАТЧИКА ТЕМПЕРАТУРИ ПРИ НЕСТАНДАРТНІЙ МЕХАНІЧНІЙ ДІЇ ОБЛАДНАННЯ АЕС
}

\author{
Ю.М. Биковський, О.В. Дерев'янко, В.В. Левченко, А.Ю. Погосов
}

Представлено результати експериментального дослідження, актуального для ефективної організації контролю температури тепломеханічного обладнання на AEC (турбін, насосів, парогенераторів, деаераторів та ін.). Проведено стендові дослідження реакції цифрового інтелектуального датчика температури DS18B20, передбачуваного до впровадження на АЕC України, на дію зовнішньої сили стиснення на його корпус, яка може виникнути в умовах, характерних для експлуатації діючого на АЕС обладнання. Розроблена електрична принципова схема пристрою імітації сигналу «скидання» (для стендового моделювання системи застосування датчика). Розглянуто питання виявлення у вихідному сигналі датчика ознаки, що інформує про вплив зовнішньої сили стиснення на його корпус. Наведено методику проведення стендових експериментів та обробки результатів досліджень, необхідних для вирішення питання про впровадження нових цифрових засобів вимірювальної техніки для контролю температури тепломеханічного обладнання АЕС. 